\title{
The Grub Street Style of Revolution: J.-P. Brissot, Police Spy
}

\section{Citation}

Darnton, Robert. 1968. The grub street style of revolution: J.-P. Brissot, police spy. Journal of Modern History 40(3): 301-327.

\section{Published Version}

http://dx.doi.org/10.1086/240206

\section{Permanent link}

http://nrs.harvard.edu/urn-3:HUL.InstRepos:3403045

\section{Terms of Use}

This article was downloaded from Harvard University's DASH repository, and is made available under the terms and conditions applicable to Other Posted Material, as set forth at http:// nrs.harvard.edu/urn-3:HUL.InstRepos:dash.current.terms-of-use\#LAA

\section{Share Your Story}

The Harvard community has made this article openly available.

Please share how this access benefits you. Submit a story.

\section{Accessibility}




\title{
The Grub Street Style of Revolution: J.-P. Brissot, Police Spy
}

\author{
Robert C. Darnton \\ Society of Fellows, Harvard University
}

Brissot's life seems a parable of his time: as one authority put it, "Il est, dès sa jeunesse, l'image complète de toutes les aspirations d'une génération." 1 This picture of the complete prerevolutionary man comes from Brissot's memoirs, where he appears steeping himself in Rousseau; publishing denunciations of decrepit institutions; forming secret revolutionary cabals; comparing insurrections with radicals of Geneva, the Low Countries, England, and the United States; reading; writing; plotting; living and breathing for the fourteenth of July. But a man seen from his memoirs looks different than when viewed from account books or police reports. A new examination of Brissot's career, based on less partial sources than the memoirs, may add some shadows and some flesh tones to the traditional portraits of him. It is undertaken, not in the voyeuristic spirit of revealing the nakedness of the man behind the memoirs, but in order to understand the making of a revolutionary and the era he is believed to typify. Brissot's prerevolutionary career seems most vulnerable to inspection at its most critical point, the two months he spent in the Bastille during the summer of 1784 .

It must have seemed to Brissot, as he contemplated the world from a window in the Bastille, that the evil powers of the Ancien Régime had united to crush him. Seven years earlier, he had set out to make himself, the thirteenth child of a tavern keeper in Chartres, into a respectable citizen of the "republic of letters," whose capitol lay in Paris. He had published thousands of pages on the appropriate subjects-the fallacies of St. Paul, the absurdities of the French legal system, the glories and weaknesses of the British constitution-and had taken the appropriately encyclopedic view of things, as could be seen by the very titles of his Correspondance universelle sur ce qui intéresse le bonheur de l'homme et de la société and De la vérité ou méditations sur les moyens de parvenir à la vérité dans toutes les connaissances humaines. He had made the conventional philosophic pilgrimages to the Switzerland of Rousseau and the England of Voltaire and Montesquieu. $\mathrm{He}$ had appealed for support to Voltaire and D'Alembert. He had competed in the essay contests sponsored by various academies and had

1 Daniel Mornet, Les origines intellectuelles de la Révolution française (17151787) (5th ed.; Paris, 1954), p. 410. 
won two prizes. He had even earned two lettres de cachet. But although he had done everything that a young writer should do, Paris had refused to grant him the standing of a philosophe.

Undaunted, he had moved to London, investing all his energy, all his ambition, and all of the four or five thousand livres that he had inherited after his father's death in 1779 into a plan to establish a "Lycée" or world center for philosophers, which would include a journal, a correspondence system, and a clubhouse. The world's philosophers, however, had failed to center around Brissot's modest home at 26 Newman Street. Very few of them corresponded with him or subscribed to his journal-so few that Brissot's partner, Desforges d'Hurecourt, who had arrived in the spring of 1784 to find the Lycée a one-man, non-profit organization lacking even the promised clubhouse, conciuded that he had been swindled and demanded the return of the thirteen thousand livres he claimed he had sunk into the enterprise. At this time the landlord and the tax collector also began clamoring for money, and Brissot's printer had him thrown into prison for debt. Brissot scraped up enough money to buy his way out but was forced to drop everything in order to find a replacement for Desforges among the speculators of Paris. While seeking to recover from the loss of his capital, Brissot lost the main market for his journal, because Vergennes, the foreign minister, revoked the permission for it to circulate in France. Then, on July 12, at one o'clock in the morning, the crowning blow fell: he was locked up in the Bastille on suspicion of having produced some pamphlets satirizing French officials. ${ }^{2}$

Brissot had expended his youth in failures and frustrated ambitions. It had brought him to this, the Bastille, and his future, as he contemplated it in his thirtieth year, must have seemed worse than his past. His first child, Félix, had been born on April 29, 1784, shortly before Brissot's departure for France, and both the infant and the mother were ailing. The Lycée was ruined; the journal could not be revived, and Desforges had begun a long, costly, and ultimately unresolved legal battle to recover his 13,000 livres and to convict Brissot for swindling. Brissot had lost all of his own investment in the Lycée and still owed large sums to his printer, paper supplier, and others. No assets remained to offset those debts, for Desforges had even sold the furniture in the Newman Street house. Imprisoned and stripped of virtually all his possessions, where was Brissot to find the 13,335

${ }^{2}$ For a more detailed account of Brissot's early life, see the carefully documented biography by Eloise Ellery, Brissot de Warville: $A$ Study in the History of the French Revolution (Boston and New York, 1915). 
livres that he needed, as he later maintained, ${ }^{3}$ in order to avoid leaving his London affairs in bankruptcy? Where was he to find a job, a home for his family, a way out of the Bastille? He had failed to become a philosophe: what was to become of him?

Temporary solutions were available for some of these problems. Brissot's mother-in-law took his wife and baby into her home at Boulogne-sur-Mer for a few months, and Mme de Genlis, his wife's former employer at the Palais Royal, helped negotiate his release from the Bastille on September 10. But another problem made his situation almost hopeless. Since August 31, 1779, he had been corresponding with the Sociéte Typographique de Neuchâtel. The correspondence, now in the Bibliothèque Publique de la Ville de Neuchâtel, provides a detailed record of his evolution as a pamphleteer and a measure of his desperate circumstances in the second half of 1784. Brissot's first letters fairly vibrate with the enthusiasm of a young man setting out to make himself into a philosophe, but by 1784 his enthusiasm disappeared under a load of financial problems. He foolishly undertook to pay for his own publications (although who else would finance the philosophizing of an unknown son of a provincial tavern keeper?) and filled the Society's books with commissions. They make a sad list of failures: about a dozen pamphlets and treatises, including his Bibliothèque philosophique du législateur, Théorie des lois criminelles, De la vérité, Testament politique de l'Angleterre, and the first volume of his Correspondance universelle. Brissot gambled that the sale of the works would pay for the cost of their publication and would establish his place as a young Voltaire or D'Alembert. He succeeded only in acquiring a reputation as a minor, rather outspoken pamphleteer and 12,301-9-0 livres $^{4}$ in debts to the Society in addition to the thousands that he owed in London.

So enormous a debt naturally worried the Society, which began dunning Brissot for its repayment shortly after his release from the Bastille. The Society also wrote to his friend, the Genevan financier Etienne Clavière, for information about Brissot's finánces and future prospects. Clavière answered that he and others had saved Brissot from being overwhelmed and that Brissot's proposals for indemnifying the Society were the utmost he could do in his desperate financial situation. The details of these proposals, based on the idea that the

3 J.-P. Brissot, Réplique de J. P. Brissot à Charles Théveneau Morande (Paris, 1791), p. 20. Brissot set his total loss from the Lycée at 18,000 livres (ibid, p. 21 ).

4 This is the Society's evaluation of Brissot's debt, according to its copy of a letter it sent to him on October 12, 1784 (Bibliothèque Publique de la Ville de Neuchâtel, MS 1110). 
Society should cover the debt by selling the books by Brissot that remained in its possession, can be read in the letters published below. They illustrate the sort of bargaining that went on between a writer and his publisher in the 1780's and provide some information about the production and circulation of radical works, which the Society printed and reprinted in large enough numbers to be described by Brissot as the source of "presque tous les bons livres politiques et philisophiques"5 that were smuggled into France. Its smuggling for Brissot had gone badly, however, for the Chambre Syndicale of the Parisian booksellers' guild, which co-operated with the police and the directeur de la librairie in regulating the book trade, had seized a shipment of the fifth volumes of his Bibliothèque philosophique. The ten-volume set would not be worth much without a fifth volume; so the powers of the Ancien Régime had delivered yet another blow to Brissot's fortune. But the confiscated volumes were milder than many works that sold openly in France, and Brissot wrote to the Society that he expected to persuade the lieutenant-général de police, Jean-Pierre Lenoir, to release them, provided that two cancels be inserted in place of some outspoken passages. By December 3, 1786, he had succeeded, and the Society sent him a bill of acquittal for his debt. No such happy ending seemed certain in 1784, however, when Brissot was attempting to extricate himself from the greatest crisis of his life before his struggle against the Mountain in 1792-93. ${ }^{6}$

\section{BOULOGNE-SUR-MER ce 22 octobre 1784}

\section{Messieurs}

Je profite du premier moment de repos que je goûte enfin à Boulogne pour éclaircir nos comptes. Je les ai examinés avec la plus mûre attention. Ils ne répondent pas entiérement à ce que je vous ai demandé par ma lettre détaillée du 3 février 1784. Ils ne dissipent pas tous mes doutes; car par exemple en rendant d'ailleurs justice à l'exactitude de vos comptes, que dois-je en penser, quand je vois annoncer dans vos anciens et nouveaux catalogues de fonds, que je tiens en main, les huit brochures imprimées

5 J.-P. Brissot, Mémoires, ed. Claude Perroud (Paris, 1911), I, 284. The Society printed at least 220 works, including d'Holbach's Système de la nature, and usually smuggled them into France by way of the Juras and Lyons. Its enormously rich papers were catalogued by $\mathbf{J}$. Jeanprêtre, who published an "Histoire de la Société Typographique de Neuchâtel, 1769-1798," Musée Neuchâtelois (1949), pp. 70-79, 115-20, 148-53.

${ }^{6}$ Brissot's letters come from the Bibliothèque Publique de la Ville de Neuchâtel, MS 1128. They were consulted by Charly Guyot for his study of FrenchNeuchâtelois relations, De Rousseau à Mirabeau, pèlerins de Môtiers et prophètes de 89 (Neuchâtel and Paris, 1936). The Society's letters come from the copies in its journal of correspondence, MS 1110, Clavière's from MS 1137. The French of the these letters has been modernized and their abbreviations written out in full. 
pour mon compte dont jamais vous ne m'avez payé un sou, et dont je vous ai payé 4 sous pour l'impression. Mais je mets cet article et les autres de côté; je veux finir; je veux dire un adieu solennel aux spéculations typographiques, et renoncer à une carrière où je me suis engagé trop imprudemment. Je connaissais trop peu le monde, et surtout le monde auquel j'avais affaire. J'ai été trompé, joué partout. Il n'est pas heureusement trop tard et je veux m'en retirer. Votre compte est un des derniers et le seul bien considérable en ce genre que j'ai à finir. Il ne tiendra pas à moi qu'il ne soit promptement terminé. Vous aviez une idée véritable de ma position, quand vous m'aviez cru trop faible pour pousser cette entreprise. J'ai cru que le commencement soutiendrait et alimenterait la fin. Mais on veut jouer de tout à la fois, et j'ai été écrasé. Nous touchons au terme. Je puis me libérer, et même voir une espèce de gain assez avantageux si vous prêtez d'oreille aux arrangements dont je vous joins ici le détail. Pénétrez-vous bien avant de les lire, de deux points; d'abord de mon honnêteté qui m'engagera jusqu'à la fin de la vie à acquitter mes engagements, quels qu'ils soient, et ensuite de ma situation actuelle. Vous connaissez mes malheurs; mais les plus doulereux, parce qu'ils se prolongent dans l'avenir, vous sont inconnus. Mon embastillement m'a ruiné. Il faut renoncer à mon éstablissement. Cet abandon me coûte plus de 20,000 livres, entraîne un procès considérable, enfin, Messieurs, je serais entièrement anéanti sans la main secourable d'un ami qui me soutient dans ma chute. Je dois à cette générosité peu commune plus de 10,000 livres qui m'étaient nécessaires pour me sauver et soutenir mon journal, le seul débris qui me reste de mon triste naufrage. Vous devez bien penser que dans une situation aussi précaire, je ne puis plus former d'engagement; d'abord parce que je n'en veux former aucun que je ne puisse acquitter, et deuxièmement parce qu'il est temps que je cesse d'abuser de la générosité de mes amis et d'épuiser leur bourse pour alimenter uniquement mon malheur. Tout cela n'est pas consolant pour vous, je le sais; de l'argent vaudrait mieux pour votre situation personelle que l'histoire de mes infortunes. Mais que puis-je faire lorsque je n'en ai point? Vous offrir mes possessions, puisque vous êtes à portée de les faire valoir, et même de gagner en les faisant valoir. C'est dans cet esprit que j'ai imaginé les propositions ci-jointes. ${ }^{7}$ Vous pourrez les modifier, y ajouter, y diminuer. Soyez bien persuadé que je me prêterai à tout ce qui conviendra à vos intérêts, et à tout ce qui pourra accélérer notre règlement. $\mathrm{Si}$ vous avez d'autres propositions à faire, écrivez-les-moi. Votre délicatesse m'est trop connue, pour que je ne compte pas sur des procédés amicaux. A un créancier dûr je dirais: toute la rigueur possible ne vous fera pas gagner un pouce. Elle vous en fera même perdre. A vous je dirai: par la douceur et la conciliation vous serez payé, et vous pouvez même sauver quelques ressources à un ami malheureux que vous avez estimé, et je suis bien convaincu que ce motif seul vous engagera à me donner une réponse satisfaisante. Je vous prie de ne pas la différer parce que je fais toutes les démarches pour faire entrer ma Bibliothèque en France et que j'ai à-peu-près la certitude de cette faveur. Je vous prie même en conséquence d'adresser sur-le-champ par la diligence de Besançon à M. Le Noir, Lieutenant-Gènèral de Police à Paris, deux exemplaires brochés des tomes 6-7-8-9 et 10 s'il est imprimé. S'il ne l'est pas, vous

${ }^{7}$ An accompanying list of books and prices has been omitted. 
l'enverrez aussitôt qu'il le sera. A propos de ce volume 10 je pense bien que vous l'aurez imprimé afin qu'on puisse mettre cet hiver cette collection en vente. Mettez sur les titres avec le nom de Desauges ${ }^{8}$ celui de Belin libraire rue St. Jacques. Vous me donnerez avis de l'envoi fait à M. Le Noir. J'ai l'honneur d'être avec toute la considération possible, Messieurs

Votre très humble et obt. serviteur BRISSOT DE WARVILLE

\section{The Society replied on November 7, 1784:}

Nous avons bien reçu en son temps l'honneur de votre lettre du $22 \mathrm{e}$. octobre dernier et ne pouvons qu'être touchés de la peinture que vous nous faites de l'état actuel de vos affaires, comme aussi de n'avoir que des voeux sincères à vous offrir pour qu'elles se rétablissent à votre satisfaction, les nôtres se trouvant telles que nous sommes obligés de solliciter le plus prompt payement possible de ce que vous nous devez et depuis si longtemps. S'il est vrai, comme nous le croyons, que vos amis vous aient aidé dans ces circonstances, nous osons affirmer qu'il n'en est vraisemblablement aucun qui se soit mis ainsi à découvert vis-à-vis de vous pour une aussi forte somme. Cependant et malgré la position incommode où nous sommes aujourd'hui, nous voulons bien, et dans les mêmes principes, consentir à nous payer, au moyen des livres que nous avons imprimés pour votre compte, mais non pas aux prix que vous nous les proposez. Vous êtes trop équitable, Monsieur, et nous en avons trop bien agi à votre égard, pour exiger qu'après avoir attendu jusqu'à ce jour le remboursement de tant d'avances en papiers et en main-d'oeuvres, sur un mince bénéfice, que les retards ont absorbé, et au-delà, nous vous passions les 9 volumes imprimés de la Bibliotheque à 1. 15-15 s. tandis que vous ne nous les payez que sur le pied de 1. 8-18-4; et la Théorie des Lois, qui ne vous coûte que 1. 1-13-9, vous la mettez à 1. 5-10, prix auquel nous ne pourrions jamais la vendre. Nous croyons donc qu'en traitant avec vous, comme nous l'avons fait avec tous les auteurs pour le compte desquels nous avons imprimé, lorsque nous nous sommes chargés d'exemplaires de leurs ouvrages en remboursement de nos avances, ce qui est votre cas, et qu'ils nous ont constamment cédés aux prix de fabrication, vous n'aurez point à vous plaindre de nos procédés à votre égard. Ainsi pour vous prouver que nous ne désirons rien de mieux que de nous arranger avec vous, Monsieur, nous prendrons pour commencer à nous remplir d'abord les 12 souscriptions pour l'atlas de $\mathrm{M}$. Mentelle ${ }^{9}$ à 1. 160 et des 300 Précis de l'histoire d'Angleterre à 30 l'exemplaire. De plus nous nous chargerons de vos trois autres ouvrages, savoir De la Vérité $8^{\circ}$, Théorie des Lois $8^{\circ}, 2$ volumes, et Bibliothèque des lois criminelles, les 9 premiers volumes, à raison d'un sol la feuille; c'est tout ce que nous pouvons faire, même en perdant de gaieté de coeur et par l'effet de nos sentiments pour vous tant par le temps nécessaire pour l'écoulement de ces ouvrages que pour l'intérêt de nos avances. Mais cette ouverture de notre part suppose, comme une condition absolument essentielle, et sans laquelle nous

8 The Parisian bookseller who handled most of Brissot's works.

${ }^{9}$ Edme Mentelle, professor of geography at the Ecole Militaire, was a close friend of Brissot and apparently offered copies of his own works to help in Brissot's bargaining with the Society. 
la retirons entièrement, qu'entre ce 7 et la fin de janvier prochain, pour le plus tard, vous nous procurez le retour de tous les exemplaires du 5e. volume de la Bibliothèque criminelle, qui ayant été envoyés à Paris par vos ordres, ont été arrêtés à la Chambre Syndicale et doivent s'y trouver encore. Nous sommes même fort surpris que vous ne nous en parlez point dans aucune de vos dernières lettres après les assurances que $M$. de Pelleport ${ }^{10}$ nous avait donné ici de votre part, touchant la facilité et la certitude d'obtenir cette restitution. Vous comprenez, Monsieur, qu'il nous est impossible de nous charger de cet ouvrage à moins qu'il ne soit complet. Nous vous prions de réfléchir sur le plan que nous vous proposons et qui nous paraît de nature à devoir être accepté de votre part, et de nous répondre la-dessus catégoriquement et le plus tôt possible, étant résolus de ne point laisser plus longtemps en souffrance.

\section{[A paragraph on other financial affairs is omitted here.]}

Le tome 10 de la Bibliothèque n'est pas encore imprimé, ne pouvant faire de nouvelles avances qu'en préalable nous ne soyons remboursés des anciennes. En supposant ce volume à 20 feuilles, tiré à 1200 à 10 d. la feuille, ce serait encore ajouter 1.1000 à votre débit chez nous. Nous ne vous dissimulerons point que nous ne sommes plus dans le cas de faire de tels frais, et que tous nos soins actuels n'ont pour but que de nous faire payer des sommes qui nous sont dues par nos divers correspondants. Nous nous persuadons aisément qu'étant homme d'honneur comme vous l'êtes, et considérant le manière généreuse et pleine de confiance dont nous en avons toujours usé envers vous, rien ne vous tiendra plus à coeur que de prendre au plutôt les mesures les plus propres pour nous satisfaire.

Le lieu d'où votre dernière est datée semble annoncer que votre intention n'est pas d'y faire un long séjour. Ainsi nous ne pouvons vous adresser notre réponse qu'à Paris sous couvert de $\mathrm{M}$. L'Arrivée ${ }^{11}$ votre ami, qui saura sans doute les moyens de vous la faire parvenir avec diligence. Il paraîtrait même que votre dessein serait de passer de Boulogne en Angleterre. Cependant certains avis nous feraient penser que vous êtes dans l'intention de vous fixer désormais à Paris; nous souhaitons sincèrement que vous preniez le parti qui vous sera le plus avantageux.

Mais afin de vous donner une idée plus claire de la manière dont nous serions disposés à nous rembourser de nos avances, par le moyen de vos ouvrages ou d'autres objets, vous trouverez ici une note de ce que nous prendrons de vous comme un acompte de notre créance, et il vous paraîtra sans doute que nous sommes très coulants à votre égard. Nous insisterons donc encore sur la nécessité d'une prompte et nette réponse.

[The note, which details the proposals to buy Brissot's books for a total of 10,207-9-6 livres, is omitted.]

On November 7, 1784, the Society wrote to Clavière, objecting to the "prix exorbitants" of Brissot's proposals to indemnify it. "Mais il nous importerait essentiellement de savoir deux choses," it emphasized. "L'une est l'état présumé de sa fortune et de ses ressources actuelles,

${ }^{10}$ Anne-Gédéon de La Fitte, marquis de Pelleport, was an extraordinary literary adventurer, who was imprisoned in the Bastille in July 1784 for an offense related to Brissot's and was not discharged until October 1788.

${ }^{11}$ Brissot's agent in Paris. 
l'autre dans laquelle des deux capitales de France ou d'Angleterre il doit désormais fixer sa résidence." Clavière replied as follows:

\section{Messieurs}

\section{PARIS ce $15 \mathrm{e}$. Novembre 1784}

La connaissance que j'ai des affaires de Monsieur de Warville et l'opinion que je me fais de ses ressources à venir, me persuadent que les offres qu'il vous a faites sont le non plus ultra de ce qui est en son pouvoir: il m'en a remis un double par lequel il me paraît qu'il fait un sacrifice considérable, et les prix auxquels il vous passe les ouvrages qu'il vous donne [en] payement me semblent tel qu'avec de la patience vous les réaliserez avec avantage; les douze atlas ne peuvent pas manquer de vous donner du bénéfice; cet ouvrage est estimé et sera très recherché dès que l'auteur aura rempli toutes ses souscriptions. J'ai entendu divers libraries parler de la Bibliothèque comme d'un ouvrage dont le débit est assuré quoique un peu lent; ces deux objets font la principale partie de ce que Mr. de Warville vous offre, et il me semble fort heureux que dans la situation où il se trouve il puisse encore s'acquitter comme il le fait; j'y contribue beaucoup en le mettant en état, par l'argent comptant que je lui ai prêté, de payer des acceptations, qui restant en souffrance l'écrasaient absolument. C'est un grand malheur pour lui de n'avoir pas connu de bonne heure combien peu il lui convenait de faire imprimer lui-même ses ouvrages: je sens bien que ce n'est pas votre faute, cependant vous devez avoir moins de regret à la manière dont il vous paye, puisque vous avez une avance considérable sur les impressions faites pour son compte. Au surplus Monsieur de Warville est trop galant homme pour ne pas vous dédommager dans le cas où la fortune le favoriserait et où vous lui montreriez une non-valeur dans son payement à laquelle il ne s'attend pas: la rigueur dont vous useriez avec lui vous serait réellement préjudiciable en ce qu'elle empirerait sa position actuelle, tandis qu'en le facilitant et le mettant à son aise vous acquérez des droits sur sa reconnaissance à laquelle il est incapable de manquer. Je vous prie d'être bien convaincus que ce que je vous dis là ne m'est dicté par aucune autre raison que celle de votre convenance ainsi que le bien de Mr. de Warville. Il est decidé jusqu'à présent à ne pas quitter la France; c'est une espèce de loi que lui a été imposée; et il compte de s'occuper aux ouvrages utiles et instructifs que ses lumières et ses talents le mettent en état de produire: il n'est point impossible qu'il obtienne un jour du gouvernement quelqu'emploi lucratif; il a paru qu'on faisait cas de son honnêteté et de ses dispositions au travail. Voilà, Messieurs, tout ce que je puis vous dire sur cet ami en réponse à l'honneur de votre lettre du 7e. courant: mettez-moi à même de vous être d'une plus grande utilité et de vous témoigner la parfaite considération avec laquelle je suis

Votre très humb. et Ot. Ser.

$$
\text { E. Clavière }
$$

[postscript in Clavière's own hand]

Soyez convaincus, Messieurs, que M. de Warville ne soit au-dessous de ses affaires, que les amis venus à son secours n'ont pour être remboursés que la liquidation du peu que lui restera des ouvrages qu'il a fait imprimer, et ce que sa plume pourra lui produire. Du reste [on voit?] sa facilité à 
[présumer?] des succès l'a commis dans des entreprises toutes ruineuses et au-delà de ce qu'il s'était imaginé. Il est plein de courage, mais ses amis qui connaissent sa situation ne laissent pas d'être tres inquiets sur la manière dont il se tirera d'affaire. En finissant avec lui vous contribuerez aux efforts qu'ils font pour le mettre au moins en état de travailler sans inquiétude.

These letters might seem to confirm the conventional picture of Brissot. They show that the climactic effort of his struggle to win a place in the world of letters had collapsed under blows from the arbitrary powers of the Ancien Régime. The seizure of his Bibliothèque shipment, the suspension of his journal's privilege, and his embastillement, on top of his financial problems, had ruined him. Only Clavière's help saved him from bankruptcy, and that help only postponed the reckoning of twenty to thirty thousand livres of debts-a sum that would have taken him at least fifty years to earn at the (admittedly miserable) salary he had received as a law clerk before he gave way to his ambition to become a philosophe! Brissot's desperate circumstances must have driven him to bitter thoughts about the political system that used the full weight of the state to crush the ambitions of provincial bourgeois. Those two months in the Bastille must have made him into a revolutionarybut not the revolutionary who has made his way into the history books, for the letters printed above raise some doubts about his relation to the powers of the French state. How is it that a man just released from the Bastille expects, as a "favor," that the head of the police will release an illegal book from the state's machinery of thought control? How is it that the government has come to esteem its former prisoner so much that it is considering hiring him? Jean Paul Marat would have had an answer to those questions:

Le voilà encore sur le pavé, sans ressources et pour surcroît de détresse, chargé d'une femme et d'un enfant. Il est notoire aujourd'hui que ne sachant de quel bois faire flèche, il se détermina à offrir ses services au sieur Lenoir lieutenant de police, qui en fit un observateur royal aux gages de 50 écus par mois. Il faisait ce beau métier lors de la prise de la Bastille; mais il le quitta forcément par la fuite de son patron ... Mais Bailly, qui menait ce corps [municipal] et qui était déjà prostitué au cabinet, l'arrêta tout court en le menaçant de montrer au public son nom inscrit dans la liste des espions de police, puis il lui promit protection et faveur s'il se rangeait adroitement de son côté. ${ }^{12}$

Because of its brutally polemical nature, Marat's accusation has never been taken seriously. Marat used it to strike back against the Girondins who, in June 1792, were attempting to flush him out of his

12 J. P. Marat, "Traits destinés au portrait du jésuite Brissot," an article in L'Ami du Peuple, June 4, 1792, reprinted in Annales révolutionnaires, V (1912), 689. 
hiding places and arrest him as an agitator. In his agitation, Marat made some factual errors, such as a statement that Brissot worked for the Duc d'Orléans (as well as Lenoir) after his American trip of 1788. But Marat also revealed some facts-about Brissot's relations with book dealers in Paris and London, for example-that only a close friend of Brissot's would have known. Marat could claim with some justice, "Personne n'a plus que moi été à portée de voir le fond de son âme,"13 in 1792, because he had then known Brissot for thirteen years. In 1783 Brissot was "mon très cher ami" to him: "Vous savez, mon très cher, la place que vous occupez dans mon coeur."14 Marat's testimony therefore seems worthy of some consideration, and the problem of whether Brissot spied for the police seems worthy of a great deal, for it provides a key test of the accuracy of the typical revolutionary man pictured in Brissot's memoirs and biographies.

Brissot's three biographers, writing under the inescapable influence of his memoirs, barely bring up the question of his spying. One doesn't mention it at all; ${ }^{15}$ another refers to it briefly as an example of the attacks made against him, ${ }^{16}$ and the third dismisses it as too slanderous for serious consideration. ${ }^{17}$ Taine accredited the charge in order to illustrate the nastiness of the revolutionary leaders, ${ }^{18}$ and Mathiez mentioned it to exemplify Girondin nastiness, although he carefully attributed it to Brissot's enemies. ${ }^{19}$ No such scruples restrained Pierre Gaxotte from repeating the charge, without bothering about evidence, in the antirevolutionary spirit of Taine. ${ }^{20}$ Among the defenders of the Revolution, Michelet, Lescure, and Louis Blanc attempted to defend Brissot, at least by implication; ${ }^{21}$ but the chief counsel for the defense 13 Ibid., p. 685.

${ }_{14}$ Marat to Brissot, in J.-P. Brissot, Correspondance et papiers, ed. Claude Perroud (Paris, 1912), p. 78. See also Brissot to Marat, June 6, 1782, in ibid., pp. 33-35.

15 Jean François-Primo, La jeunesse de Brissot (Paris, 1939).

16 Ellery, p. 268.

${ }^{17}$ Claude Perroud's account of Brissot's life, probably the most influential one in French, in his edition of Brissot's Correspondance et papiers (cited in n. 14 above), p. xxxv.

18 Hippolyte Taine, Les origines de la France contemporaine: La Révolution (15th ed.; Paris, 1894), II, 133.

${ }^{19}$ Albert Mathiez, La Révolution française (Paris, 1922), I, 186. Mathiez's hostile portrait of Brissot resembles that by his master, Jean Jaurès, who did not, however, mention the spying charge (Jean Jaurès, Histoire socialiste de la Révolution française, ed. Albert Mathiez [Paris, 1923], III, 69).

${ }^{20}$ Pierre Gaxotte, La Révolution française (Paris, 1928), p. 233.

21 Jules Michelet, Histoire de la Révolution française ("Bibliothèque de la Pléiade," ed. Gérald Walter [Paris, 1952]). I, 850-51, 862; II, 47; M. F. A. de Lescure (ed.), Mémoires de Brissot (Paris, 1877), pp. xl, lvi; Louis Blanc, Histoire de la Révolution française (Paris, 1847-62), VI, 289-92; VIII, 500. Although the other historians of the Revolution have not pronounced on Bris- 
was Alphonse Aulard, whose habit of drawing morals from the lives of the revolutionaries ("Toute sa vie l'homme d'état adora sa mère comme il adorait la France: les grands patriotes de la Convention étaient tous de bons fils," ${ }^{22}$ he told the children of the Third Republic in his biography of Danton) inspired an indignant rebuttal of Taine. In his edition of Les origines de la France contemporaine, Aulard drew an angry line next to Taine's portrait of Brissot: "Ce malheureux, né dans une boutique de pâtissier, élevé dans un bureau de procureur, ancien agent de police à 150 francs par mois, ancien associé des marchands de diffamation et des entrepreneurs de chantage, aventurier de plume, brouillon et touche-à-tout." ${ }^{23}$ And he cited this passage in an attack on Brissot's attackers: "Ils hésiteraient, devant cette confession si honnête [Brissot's memoirs, which Aulard accepted as the picture of the true Brissot], à dire que ce propagateur généreux des idées philosophiques ne fut qu'un vil agent de police à 150 francs par mois, comme on l'imprimait hier encore, sans daigner produire l'ombre d'une preuve."24 Taine did not disdain documentation for want of evidence: like most writers concerned with the Girondin-Montagnard conflict, he carefully selected his material from the torrent of denunciations and personal abuse that filled the debates of the revolutionary assemblies and the columns of the revolutionary journals. It seems best, then, to turn from the historians to the revolutionaries themselves in order to examine Brissot's reputation as a police spy.

The spying charge led the list of accusations against Brissot in the indictment of the Girondins presented by Andre Amar to the Committee of General Security on October 3, 1793. Speaking for the victorious Montagnards, Amar attached the epithet "agent de police sous les rois" to Brissot's name and pointed him toward the guillotine. It was a brief

sot's alleged spying, they have unavoidably assessed his role as a leader of the Girondins. The more recent assessments by Georges Lefebvre, J. M. Thompson, and Crane Brinton credit his honesty and idealism, if not his political genius. They show more indulgence for him, oddly, than Lamartine, who voiced skepticism about the integrity of the "homme mixte, moitié d'intrigue, moitié de vertu," at least in the beginning of his apologia for the Girondins; by the end, Brissot walked to the guillotine with his colleagues as the apotheosis of moderate Revolutionary idealism. See Georges Lefebvre, La Révolution française ("Peuples et civilisations," Vol. XIII [Paris, 1951]), p. 226; J. M. Thompson, Leaders of the French Revolution (New York, 1962), pp. 67-91; Crane Brinton, A Decade of Revolution, 1789-1799 ("The Rise of Modern Europe," Vol. XI [New York and London, 1934]), p. 106; and Alphonse de Lamartine, Histoire des Girondins (Paris, 1847), I, 235-41 (quotation from p. 241); VII, 36.

${ }^{22}$ F. A. Aulard, Danton (Paris, 1903), p. 8.

${ }_{23}$ Taine, II, 133, in Widener Library, Cambridge, Mass., Fr. 1327.144.5.

${ }^{24}$ F. A. Aulard, Les orateurs de la Révolution: La Législative et la Convention (Paris, 1906), I, 218-63, quotation from p. 221. 
remark, tossed off by way of introduction to an analysis of Brissot's role in the Revolution, and it was not repeated in the report against Brissot and the other Girondins that Saint-Just delivered for the Committee of Public Safety to the Convention on July $8 ; 25$ but Brissot took it seriously enough to refute it at some length in his "Projet de défense devant le Tribunal Révolutionnaire." Once more imprisoned, but this time with his life at stake, he attempted to justify his career to both the Revolutionary Tribunal and posterity. As in his memoirs, which were written under the same circumstances, he presented himself as a disinterested idealist, the very antithesis of a police spy:

Et je me suis toujours montré l'implacable ennemi du règne inquisitorial de la police! Et je n'ai eu d'autres rapports avec le ministre et la police que d'avoir été frappé de trois lettres de cachet pour mes écrits en faveur de la liberté; que d'avoir été mis par lui à la Bastille pendant deux mois, que d'avoir vu prohiber et saisir par lui presque tous mes ouvrages! Et depuis 1779 jusqu'à la destruction de la police, en 1789 , j'ai publié chaque année des ouvrages contre le gouvernement; et la police, m'environnant sans cesse de ses espions, n'a cessé de me tracasser! Comment donc aurais-je été l'instrument d'un ministre qui me persécutait et que je démasquais! ${ }^{26}$

Brissot may have felt a need to insist on his innocence because his enemies had been repeating Marat's denunciation of June 4, 1792 with increasing frequency as the struggle between the Girondins and the Montagnards became more and more fierce. On November 14, 1792 François Chabot brought a violent attack on Brissot in the Jacobins to a climax by accusing Brissot of being an "ancien espion de police," 27 and Anacharsis Cloots echoed this accusation in a speech to the Jacobins on November $26 .{ }^{28}$ An anonymous pamphlet published

${ }^{25}$ André Amar, "Acte d'accusation contre plusieurs membres de la Convention Nationale, présenté au nom du Comité de Sûreté Générale, par André Amar, membre de ce Comité," Réimpression de l'ancien Moniteur (Paris, 1841), Oct. 25, 1793, XVIII, 200. The charge, together with other references to Brissot's prerevolutionary career, was lost in the verbose, confusing, and inconclusive testimony about the intrigues and policies of the Girondins, as reported in the Moniteur and the Bulletin du Tribunal Criminel Révolutionnaire (Paris, 1793), nos. 34-64, pp. 133-256. The biased editors of these publications may have cut a reply by Brissot to the accusation of spying, for they interrupted his testimony at one point with the same remark: "L'accusé fait ici une longue et verbueuse apologie de sa conduite" (ibid., p. 181). Saint-Just had little to say about Brissot's prerevolutionary career: his report is in the Moniteur, July 18 and 19,1793 , XVIII, 146-50, 153-58.

${ }^{26}$ Brissot, Mémoires, II, 277.

${ }^{27}$ François Chabot à Jean-Pierre [sic] Brissot (1792).

${ }^{28}$ Cloots clearly aimed his attack at Brissot but did not mention him by name. The speech is in F. A. Aulard, La Société des Jacobins: Recueil de documents pour l'histoire du club des Jacobins de Paris (Paris, 1889-97), IV, 520. 
between June and October 1793 prepared the country for Brissot's execution by denouncing "le rôle infâme qu'il avait joué sous les tyrans secondaires de la police." It cast him in this role as soon as he first arrived in Paris and then added enough fictitious detail to make him into an unrecognizable villian. ${ }^{29}$ Robespierre made Brissot's corruptibility official dogma in a speech denouncing the "lâche espion de police" to the Convention on June 24, 1793.30 But it was Camille Desmoulins who did more than anyone else to spread Brissot's reputation as a spy. Desmoulins reportedly exclaimed after the Revolutionary Tribunal sentenced the Girondins to death on October 30, 1793, "Ah mon dieu, mon dieu; c'est moi qui les tue: mon Brissot dévoilé, ah mon dieu, c'est ce qui les tue." ${ }^{11}$ This pamphlet, the cleverest, most effective attack ever made against Brissot, contained a letter that Desmoulins attributed to the Baron de Grimm: "Vous me dites que Brissot de Warville est un bon républicain. Oui; mais il fut l'espion de M. Lenoir, à 150 livres par mois; je le défie de le nier, et j'ajoute qu'il fut chassé de la police parce que Lafayette, qui dès lors commençait à intriguer, l'avait corrompu et pris à son service." 32 As Desmoulins must have known, the letter was really a diatribe against Volney by Rivarol, entitled Réponse de $M$. le Baron de Grimm ... à la lettre de M. Chasseboeuf de Volney, dated January 1, 1792. The remark about Brissot had nothing to do with the main theme of the letter. Rivarol apparently added it as a sort of postscript in order to vent some personal resentment or to support his prejudiced but penetrating argument that the Revolution recruited its leaders from the ambitious mediocrities, who, unlike himself, had not been able to make it to the top during the Ancien Régime. ${ }^{33}$

29 Vie privée et politique de Brissot (Paris, An II), p. 12.

30 Oeuvres de Maximilien Robespierre, ed. Marc Bouloiseau, Georges Lefebvre, Jean Dautry, and Albert Soboul (Paris, 1958), IX, 592. p. 51 .

31 Joachim Vilate, Les mystères de la mère de dieu dévoilés (Paris, An III),

32 Jean-Pierre [sic] Brissot démasqué (orginally published in February 1792), in Oeuvres de Camille Desmoulins, ed. Jules Claretie (Paris, 1874), I, 267. Desmoulins did not repeat the charge in his Histoire des Brissotins, published in May 1793.

33 Rivarol's letter, reprinted in Ecrits et pamphlets de Rivarol, recueillis pour la premiére fois et annotés par A. P.-Malassis (Paris, 1877), contains the remark, exactly as Desmoulins reported it, on p. 115. Following an article by Maurice Tourneux in L'intermédiaire des chercheurs et des curieux, XXIV (Jan. 25, 1891), 62, Miss Ellery (pp. 243-44) traces the Rivarol letter to Les Actes des Apôtres, no. 261. This number, however, contains only some irrelevant "Fragments de la correspondance secréte du Baron de Grimm avec la première fonctionnaire publique de toutes les Russies." Tourneux attributed the Rivarol letter to another issue of Les Actes des Apôtres in his edition of the Correspondance littéraire, philosophique et critique par Grimm, Diderot, Raynal, Meister, etc. (Paris, 1880), XVI, 265, but the present writer has not been able 


\section{Robert C. Darnton}

Rivarol was but one of Brissot's enemies from the early stages of the Revolution who provided ammunition for the Montagnard attacks of 1792 and 1793. Brissot put his finger on some of the Montagnards' other sources when he defended himself against the accusation of spying in his "Projet de défense:" "Cette infâme calomnie, imaginée d'abord par des aristocrates, répandue par Gouy d'Arsy, par Théodore Lameth, a été démentie par moi dans tous les journaux; je leur ai porté le défi formel d'en donner des preuves, et ces vils calomniateurs n'ont osé me répondre; et voilà les hommes qui [sic] copient aujourd'hui les républicains pour diffamer un des plus zélés défenseurs du républicanisme!" ${ }_{4}$

The Marquis de Gouy d'Arsy, an aristocrat and slave owner who had passed as a radical in 1789, turned against Brissot in early 1791, because Brissot, then a spokesman for the radical cause and a leader of the Société des Amis des Noirs, was directing a campaign to get the Constituent Assembly to abolish the slave trade. Pitting as it did the commercial interests of the coastal towns against the revolutionary principles of liberty and equality and the humanitarian sentiments of the time, the slave-trade issue provoked some envenomed pamphleteering. In a characteristic pamphlet against Brissot, Gouy d'Arsy charged that, far from serving humanity, the "ami des noirs" had been in the service of the Parisian police; and Brissot replied with an equally outspoken pamphlet, containing a defiant statement of his innocence, which he reprinted in his newspaper, Le Patriote Français, of November 3, 1791: "Vous me mettez en correspondance avec le ci-devant lieutenant de police, Lenoir; vous me gratifiez de ses commissions de confiance. Il m'a mis à la Bastille; voilà la seule marque de confiance qu'il m'a donnée. Je ne le connaissais pas avant, et je ne l'ai jamais vu depuis. Prouvez le contraire, je vous en défie." ${ }^{35}$

Brissot confronted another accuser with the same defiance in $L e$ Patriote Français of March 20, 1792: "Il a insinué que j'étais aux gages de l'ancienne police. Je l'ai sommé, $1^{\circ}$. de signer, $2^{\circ}$. de répéter, $3^{\circ}$. de fournir des preuves: or il signe, ne dit pas un mot de la calomnie, ne cite aucune preuve: donc il est constitué par son silence même un calomniateur." The enemy this time was François de Pange, an aristocrat who wanted to keep the Revolution from moving beyond the limits of a con-

to find the original. Rivarol and Champcenetz expressed their views of the Revolution's leaders in Petit dictionnaire des grands hommes de la Révolution (1790), which contains a satirical attack on Brissot.

34 Brissot, Mémoires, II, 277.

35 J.-P. Brissot, Réplique de J. P. Brissot à la Premiére et dernière lettre de Louis-Marthe Gouy, défenseur de la traite des noirs et de l'esclavage (Paris, 1791 ), p. 42; Le Patriote Français, Feb. 3, 1791. 
servative constitutional monarchy. In the spring of 1792 , he and several other Feuillant sympathizers filled the Journal de Paris with attacks on Brissot, who by then had become one of the most powerful members of the Legislative Assembly. Pange posed as a spokesman of the informed public's opinion of Brissot: "Des curieux ... ont écrit qu'on l'a vu aux gages de l'ancienne police;" and he made clear his attempt to accredit this rumor by observing that it might explain Brissot's praise of the French monarchy, the police, and even Lenoir himself-_un ministre ami de l'humanité," Brissot had called him-in a pamphlet written in $1780 .{ }^{36}$ To Brissot's demand for proof of his alleged spying, Pange merely replied that Brissot's pamphlet proved him worthy of it; and Pange's friend André Chénier elaborated on this argument in a letter to the Journal de Paris of March 19, 1792. Pange and Chénier had no real interest in proofs or even in the accusation; they wanted to discredit the radical stand of the "Brissotins" by presenting Brissot as an opportunistic hypocrite: "C'est un trafiquant de pensées qui toujours a consulté le goût public pour n'étaler que celles dont le débit était avantageux."37

The charge of spying was equally irrelevant to the quarrel that arose between Brissot and Théodore Lameth in March 1791. Lameth backed a group of conservative citizens from Lons-le-Saunier, who claimed affiliation with the Parisian Jacobin Club, and Brissot championed a rival local group, branding the Lameth faction as aristocrats. Lameth retaliated with a smear campaign, according to the attack on him that Brissot published in Le Patriote Français of March 7, 1791: "Un homme digne de foi m'assure que vous avez dit que j'étais payé par M. la Fayette, et que j'ai été espion de police, et que vous en avez des preuves." Having challenged Lameth to produce his evidence and having received no reply, Brissot continued, "Je lui donne donc un démenti formel; je le somme de publier ses preuves, et s'il ne le fait pas, le public doit le regarder comme un vil calomniateur." ${ }^{38}$ In this case, too, Brissot had aroused the hostility of the right wing, for he was on the verge of preaching republicanism while the Lameth brothers,

36 Journal de Paris, Mar. 13, 1792. See also Pange's articles in the Journal de Paris of March 18 and 25, 1792 and the anonymous attacks on Brissot in the issues of March 6 and 16, 1792. Brissot's pamphlet, Les moyens d'adoucir la rigueur des lois pénales en France ... (Châlons-sur-Marne, 1781), praised Lenoir on p. 43.

37 Journal de Paris, Mar. 13, 1792. Chénier's letter criticized the "lâcheté" of such praise, but it shied away from a direct challenge to Brissot on the spying issue, contrary to the inaccurate account of it in Vernon Loggins, André Chénier: His Life, Death and Glory (Athens, Ohio, 1965), p. 161.

${ }^{38}$ Le Patriote Français, Mar. 7, 1791. For background on this quarrel, see ibid., Mar. 13, 1791. 


\section{Robert C. Darnton}

with Barnave, Duport, and the occasional collaboration of Lafayette, were laying the basis of the conservative Feuillant coalition.

The charges about spying, attached arbitrarily to a succession of unrelated issues, dogged Brissot throughout his revolutionary career. They appeared whenever he became entangled in polemics, first when he fought the efforts of conservatives to stop the progress of the Revolution, later when he himself tried to stop it. The course of the Revolution seemed always to be at stake in the accusations and counteraccusations, yet the debate itself rarely rose above the level of personal vituperation. It does not provide much information about Brissot's past, but it illustrates the character of revolutionary polemics: as before the Revolution, the French debated about personalities and scandals more readily than policies. The Feuillants argued for a constitutional monarchy and the Montagnards for an egalitarian republic by accusing Brissot of having been a police spy. They decorated their speeches with abstractions drawn from Rousseau, Montesquieu, and classical authors, but they seemed really to be getting down to the business of politics when they began hurling denunciations about the relations of Brissot and Lenoir, Pétion and Mme de Genlis, Marie Antoinette and the Cardinal de Rohan, or Orléans and anybody. One can't even find the origin of the spying charge in the undergrowth of libelles surrounding Brissot's reputation. What seems to be the earliest reference to it is perhaps the most typical. A letter addressed to Brissot, reprinted in Le Patriote français of October 7, 1790, revealed that "un écrivain très connu" had said that "dans un certain public ... on prétend avoir vu madame votre épouse aller recevoir (sous l'ancien régime) une pension de M. le Noir." Brissot replied indignantly, "C'est une fable que cette pension, jamais mon épouse n'en a obtenue [sic] ni demandée [sic]. Mon embastillement me coûte 20 à 25,000 livres; je n'ai pas eu un sou de dédommagement." 39 Thus, by October 1790, the rumor was in the air, available to whomever needed a weapon against Brissot and the sort of revolution he represented. But was Brissot a police spy?

The rumor mongering gave Brissot a dubious reputation and may provoke some smoke-to-fire inferences; but the rumors reveal the natural inconsistencies of the Parisian on dit, and they cannot be squared with some reliable facts. Lenoir was lieutenant-général de police from August 1774 to May 1775 and from June 1776 to August 1785. Marat must be wrong, then, in stating that Brissot asked to spy for Lenoir after leaving the Palais Royal (around August 1787) and after returning from the United States (January 1789); and there is no evidence for Marat's charge that Bailly won Brissot's support by threat-

39 Ibid., Oct. 7, 1790. 
ening to reveal his connections with Lenoir. According to the Vie privée, Brissot began spying as soon as he first settled in Paris (MayAugust 1774), but Brissot, then a twenty-year-old law clerk, had neither the financial need nor the contacts to make a spy at that time. Pange made Brissot a spy in 1780, an equally unlikely time, because Brissot had then recently inherited enough money to have hopes of building a respectable literary reputation for himself. Hébert added another variation to the charge by suggesting to the Revolutionary Tribunal that Brissot had done his spying for the English, evidently after 1789, but Hébert's testimony is convincing only as a crude call for the guillotine. ${ }^{40}$ Desmoulins, Rivarol, and Brissot's other enemies did not attach dates or many details to their accusations, which read like a succession of slanders passed from anti-Brissotin to anti-Brissotin as the Revolution progressed. The revolutionaries' habit of dealing in denunciations ("La loi punit de mort le contrefacteur; la nation récompense le dénonciateur" said a slogan printed on the assignats) makes the attacks on Brissot seem almost natural; in fact it is surprising to find the spy reference missing in the denunciations of Saint-Just and Théveneau de Morande, an old enemy who produced a violent pamphleteering campaign against Brissot during the elections to the Legislative Assembly. ${ }^{41}$ When one considers the confident tone of Brissot's denials of the charge and his reputation for integrity, at least among some discriminating observers, ${ }^{42}$ one feels inclined to agree with Aulard and Brissot's biographers: the accusation of spying seems a fantasy of Brissot's enemies, used for polemical purposes.

How disturbing, then, to find the following remarks in the manuscripts of Jean-Pierre Lenoir, the lieutenant-général de police who knew

${ }^{40}$ Bulletin du Tribunal Criminel Révolutionnaire, no. 45, p. 177. An even more fanciful version of Brissot's career, attributed to Jcel Barlow, made him an "agent of the police" well after the fall of the Bastille: "A Sketch of the Life of J. P. Brissot by the Editor" in a translation of Brissot's Nouveau voyage dans les Etats-Unis ..., entitled New Travels in the United States of America Performed in M.DCC. LXXXVIII by J. P. Brissot de Warville (London, 1794), II, $\mathrm{xxx}$.

41 The most effective in the barrage of pamphlets that Morande delivered against Brissot was Réplique de Charles Théveneau Morande a Jacques-Pierre Brissot sur les erreurs, les oublis, les infidélités et les calomnies de sa Réponse (Paris, 1791). The accusation of spying also failed to appear in the somewhat milder volleys of pamphlets exchanged between Brissot and Stanislas de ClermontTonnerre in the autumn of 1790 .

42 Etienne Dumont, who kept a sense of objectivity in his friendship with Brissot, considered him a virtuous but dangerously partisan zealot: Souvenirs sur Mirabeau et sur les deux premières assemblées législatives, ed. Joseph Bénétruy (Paris, 1951), pp. 178, 192, 203. Other friends of Brissot, notably Pétion and Mme Roland, produced stronger but more biased declarations of faith in his honesty. 


\section{Robert C. Darnton}

more about the secret activities of Paris than anyone else: "Brissot resta à Paris [after his release from the Bastille]; il y vint offrir ses services à la police; je les refusai mais il eut pendant près d'un an des relations d'espionnage avec l'un des secrétaires de ce département, qui me présentait ses rapports, et ses rapports lui étaient payés. Peu avant ma retraite [August 1785], Brissot resta d'être employé comme espion à la police."43 Lenoir's statement should be accepted with caution, for it was written in exile, when he had no love for Revolutionaries, and it described events that had occurred at least fifteen years earlier. It is to be found among the scraps of notes that Lenoir intended to assemble into memoirs, memoirs that might have been just as biased as Brissot's. Lenoir evidently had original documents to assist his memory, but he also had resentments to distort it, and he had a case to defend: he wanted to show that the old system of policing Paris was far more effective and far less despotic than the revolutionaries maintained. Whether Lenoir had any personal resentments against Brissot seems doubtful. As already mentioned, Brissot's enemies impugned his patriotism in 1791 because he had praised Lenoir in one of his earliest pamphlets. By this time, however, Brissot had offset this praise with some suitably revolutionary descriptions of Lenoir. One pictured the head of the police and his lackies "quand, dans leurs soupers fins, en sablant le vin de Champagne avec les jolies femmes qu'on enlevait à leurs maris, ils plaisantaient sur les écrits philosophiques de ces têtes exaltées qu'ils tenaient dans les cachots de la Bastille, sur l'imbécilité du peuple, qu'ils muselaient, et dont ils buvaient le sang et les sueurs." ${ }^{44}$ Such slander, if it ever penetrated his place of exile, might have provoked Lenoir to slander Brissot in return; but Brissot's remarks were restrained in comparison with those of other journalists, who made Lenoir into a leading villain of revolutionary folklore. Brissot's friend Jean-Louis Carra, for example, outdid him by far in publicizing the Lenoir of chains and cachots as a symbol of the Ancien Régime's despotism. Actually, the lieutenant-général de police seems to have been an honest, quite undespotic civil servant-too honest, in fact, to have lied about Brissot in the unlikely event that he had a motive to do so.

43 Bibliothèque Municipale d'Orléans, MS 1422. After looking through these papers, Georges Lefebvre found no reason to doubt their authenticity: "Les papiers de Lenoir," Annales historiques de la Révolution française, IV (1927), 300. On Lenoir and the police of Paris, see Maxime de Sars, Le Noir, lieutenant de police 1732-1807 (Paris, 1948).

${ }_{44}$ Le Patriote Français, Aug. 10, 1790. It may be relevant to note that in 1781 Brissot expressed horror at police spying: Théorie des lois criminelles ("Berlin," 1781), II, 177. For the character of the anti-Lenoir pamphleteering, see Jean-Louis Carra's opening attack, L'An 1787. Précis de l'administration de la bibliothèque du roi sous Mr. Le Noir (Liège, 1788). 
Brissot's denials of the spying charges seem strong, but how could he have ignored them or denied them weakly? He may have felt safe in challenging his accusors to produce evidence of his spying, for he knew that his police record had disappeared from the ruins of the Bastille. His close friend Pierre Louis Manuel had given it to him, "en me disant qu'il ne fallait pas qu'il restât rien de moi dans les ordures de la police." ${ }_{45}$ The Bastille archives in the Arsénal contain a suggestive gap where Brissot's dossier would have been; and where they do mention his name-in scattered, routine reports-they contradict the larmoyant account of his imprisonment that he published during the Revolution: "Je languissais dans les cachots, moi, innocent! ... séquestré de tout le genre humain, de ma femme, de mon enfant, auxquels on refusait de laisser parvenir mes lettres, en me jurant qu'elles leur parvenaient... Les barbares se jouaient de mes pleurs, et de leurs tourments!" 46 Not only did the barbarians not refuse Brissot's requests to communicate with his family, but Lenoir wrote to the Marquis de Launay, the Bastille's governor, on August 23, 1784, "Je prie Monsieur le gouverneur de permettre au sieur de Warville de voir la dame de Warville son épouse, en prenant les précautions d'usage." A note by de Launay shows that the couple's first meeting took place "le 24, depuis neuf heures et demie jusqu'à dix et demie."47

Brissot had good reasons during the Revolution to exploit the myth of the Bastille by picturing himself as a martyr of royal despotism. When Manuel and his colleagues were preparing the publication of La Bastille dévoilée, a carefully edited selection of the papers they had collected from the Bastille, they asked Brissot to write his own article, instead of surrendering the documents concerning him; and he wrote predictably that "la vraie cause de ma détention a été le zèle avec lequel j'ai de tout temps et dans tous mes écrits défendu les principes qui triomphent aujourd'hui." ${ }^{48}$ Manuel must have doctored the article about his own em-

45 Brissot, Mémoires, II, 23.

46 J.-P. Brissot, J. P. Brissot, membre du comité de recherches de la municipalité à Stanislas Clermont ... (Paris, 1790), pp. 34-35. The most important gap in the papers at the Bibliothèque de l'Arsénal comes in MS 12454, which contains nothing about Brissot but a great deal about his fellow prisoners of 1784 , notably his old friend, the Marquis de Pelleport, who was arrested in connection with Brissot on the charge of producing libelles against members of the French court. Other police records concerning Brissot may have been destroyed with the Hôtel de Ville in 1871.

${ }_{47}$ Bibliothèque de l'Arsénal, MS 12517, fol. 77 bis. Other reports establish that Brissot was well supplied with laundry, food, and opportunities to take walks within the prison walls.

48 P. L. Manuel et al., La Bastille dévoilée, ou recueil de pièces authentiques pour servir à son histoire (Paris, 1789), troisième livraison, p. 78. How much of this work can be attributed to Manuel is doubtful. He seems to have been one 
bastillement, for it stated that he had been imprisoned in 1786 for having distributed an innocent pamphlet about the Affaire du Collier and some others by Mirabeau. The records of his interrogations survive, because they were captured from him in 1793; and they show that he had been arrested for peddling pornography. ${ }^{49} \mathrm{Did}$ he want to hide the nature of his existence as a hack writer before the Revolution and to do the same for a friend who had shared it with him? The hypothesis seems credible, for Lenoir revealed that Manuel, too, had spied for the police. In a note about clandestine publishing in Paris, Lenoir wrote, "Manuel, écrivain tout-à-la-fois et colporteur qui alors servait d'espion salarié par un inspecteur de police, dénonça avoir vu des obscénités sortant de l'imprimerie du Mazarin que tenait clandestinement Sauson dans un endroit dépendant de l'Hôtel du Contrôle des finances." 50 No amount of editing could erase all the marks made on a man by the hard life of Grub Street.

There is no getting around it: unless Lenoir was lying, Brissot was a spy and a liar, too. Brissot's publications, especially his memoirs, do not offer much evidence of his truthfulness. They misconstrue, to say the least, his relations with Lafayette, Dumouriez, and Orléans; his role during the Varennes crisis and the insurrection of August 10, 1792; the purpose of his trip to the United States; the nature of his Lycée; and his interest in the Bourse and in pamphleteering. His treatise on truth belonged to the beginning of his career; by 1789 truth had become entangled in polemics, and by 1793 it lay hidden in the shadow of the guillotine. However much one sympathizes with his circumstances, it is difficult to deny that they made him more likely than Lenoir to falsify the past.

In defense of Brissot, it should be remembered that "spying" for the police could take the form of reporting on the mood of certain sections or milieux of the city rather than betraying friends. Spies, often called mouches (a term apparently derived from the name of the notorious sixteenth-century agent Antoine Mouchy), buzzed like flies around the cafés and public places where gossip was to be gathered. They often made reports on individuals known for corrupt morals or radical religious and political opinions. Lenoir possessed a report on Brissot, for example, which typifies the genre: "BRISSOT, écrivain, est plus dangereux qu'on ne pense. Il a l'âme d'un scélérat sous une petite enveloppe douce en apparence. Sa femme, si elle est sa femme, semble honnête. Il a été lié à Genève avec des bannis de cette ville. Il y a

of several writers who used the papers of the Bastille as a source for some sensational, lucrative, and safely expurgated pamphleteering.

49 Archives Nationales, W295; Manuel et al., pp. 105-6.

50 Bibliothèque Municipale d'Orléans, MS 1422. 
fréquenté un anglais nommé Pigot, homme méchant, extraordinaire, fort riche qui a des maisons partout, hors son pays qu'il a abandonné. On dit que Brissot était à Genève comme son ami, son écrivain et son secrétaire." 51

Brissot had enough contact among the down-and-out writers and salon radicals in Paris to have written many reports like this, but it may be that his spying consisted in reporting and manipulating rumors, as is indicated by a fragment of Lenoir's papers that Jacques Peuchet, a police archivist, claimed to publish: "Le fameux Comte de Mirabeau et Brissot de Varville avaient été séparément occupés par la police à faire des écrits, des bulletins et à les répandre dans le public pour contredire de fausses histoires et anecdotes." 52 Brissot may have supplied the police with reports on the blackmailers and smut peddlers known as libellistes and sommateurs who made up the colony of French expatriates in London before 1789. Brissot knew this colony well; he had received his training in journalism from it, and he blamed his embastillement on its leader, Charles Théveneau de Morande, a literary buccaneer, political pornographer, and sometime police agent-diplomat, who backed Desforges in his quarrel with Brissot about the Lycée. During his interrogation in the Bastille, Brissot must have been able to tell Lenoir a good deal more than he admitted in his memoirs about the Naissance $d u$ Dauphin, the Petits soupers de l'hôtel de Bouillon, the Rois de France dégénérés, the Passe-temps d'Antoinette et du vizir de Vergennes the Diable dans un bénitier, and other such pamphlets that the London libellistes smuggled into France or surrendered for a ransom to the Parisian police. ${ }^{53}$ A letter from Brissot's agent in Ostend exposed the falsehood of his claim that he had nothing to do, "ni directement, ni

51 Bibliothèque Municipale d'Orléans, MS 1423, entitled "Rapport des inspecteurs ayant les départements de la librairie et des étrangers." Robert Pigott was a radical English Quaker, who was still in touch with Brissot during the early years of the Revolution, when he contributed articles to Le Patriote Français.

52 Jacques Peuchet, Mémoires tirés des archives de la police de Paris (Paris, 1838), III, 17. Peuchet added that he himself did not credit this report (ibid., p. 18), but it would not contradict the picture of Mirabeau's checkered career that emerges from Charles de Loménie's Les Mirabeau, nouvelles études sur la société française au $18^{\circ}$ siècle (Paris, 1889), Vols. III and IV, and Jean Bouchary's Les manieurs d'argent à Paris à la fin du XVIII siècle (Paris, 1939), Vol. I. The latter has been incorporated in Joseph Bénétruy's L'Atelier de Mirabeau: Quatre proscrits genevois dans la tourmente révolutionnaire (Geneva and Paris, 1962). In an almost illegible note among his papers, Lenoir scribbled, "Le fameux Comte de Mirabeau avait été employé par le lieutenant de police, le fameux Brissot de Warville de même. La police les occupait à faire (répandre et annoncer?) des pamphlets" (Bibliothèque Municipale d'Orléans, MS 1422).

53 Brissot, Mémoires, II, 7-8. See also Paul Robiquet, Théveneau de Morande, étude sur le XVIII ${ }^{\bullet}$ siècle (Paris, 1882). 
indirectement," with the last-named pamphlet; ${ }^{54}$ and a letter in the manuscripts of the Société Typographique de Neuchâtel proves, as Marat maintained, that Brissot was involved in the production of much stronger pornography than Les liaisons dangereuses, which outraged his moral sensitivity, according to reviews that he published in two of his journals. ${ }^{55}$ Moral sensitivity was a standard attribute of a prerevolutionary pamphleteer and so was a need for money.

Like his fellow pamphleteers, Brissot learned to work within the baroque bureaucracy that attempted to control and at times to exploit the printed word in France. His book dealer and a police agent called Goupil de Pallières gave him his first lesson in 1777 , during a ceremony that they staged for the announcement of his first lettre de cachet. Goupil played his part delicately: Brissot should prepare himself for some bad news; he had foolishly insulted the wife of an attorney in his brochure, Le pot-pourri, a mere "étourderie," to be sure, but one that would take him to the Bastille if he did not disappear before the next morning, when Goupil would arrive with the lettre de cachet and expect to collect, as evidence of zealous law enforcement, some pages of the manuscript that Monsieur would be pleased to leave behind. Goupil later asked to be compensated in forbidden pamphlets, which he evidently planned to peddle, because he was thrown in the Bastille himself during the next year for giving his wife pamphlets to hawk from his collection of confiscated works. ${ }^{56}$ Because of the nature of the place, police and pamphleteers often lived symbiotically in Grub Street. Of course Brissot claimed in his memoirs that this environment never infected him, but he sounded less innocent in his letters to his publishers.

These read as if they were written from inside the Hôtel de la Police. On July 26, 1781, for example, Brissot warned the Société

54 Brissot, Réplique ... à Morande, p. 25. Brissot added, "J'ai toujours eu en horreur surtout le genre des libelles privés." Brissot did not challenge the authenticity of the letter from his agent, Vingtaine, dated April 3, 1784, which Morande printed in his Réplique ... à Brissot, p. 106. The extensive correspondence about the libellistes in the archives of the Ministère des Affaires Etrangères (Correspondance politique, Angleterre, MSS 541-49) treats Brissot as a companion but not an accomplice of them.

55 Marat, p. 686. On September 16, 1781, the Society wrote to Brissot, refusing to print an obscene work that he had sent on behalf of Desauges (Bibliothèque Publique de la Ville de Neuchâtel, MS 1109); yet it printed a pirated edition of Les liaisons dangereuses, which Brissot reviewed with horror in his Journal du Licée [sic] de Londres (London, 1784), I, 389-91, and his Correspondance universelle sur ce qui intéresse le bonheur de l'homme et de la société (London, 1783), where he maintained, "Un roman dont la morale est équivoque est un poison bien dangereux" (p. 124). The Society sold, but did not print, much pornography, including some written by Mirabeau and published in Neuchâtel by its former partner, Samuel Fauche.

56 Brissot, Mémoires, I, 104-6. 
Typographique de Neuchâtel to take care with its shipments of Raynal's recently condemned Histoire philosophique et politique des établissements des européens dans les deux Indes:

L'intérêt que je prends à tout ce qui vous concerne m'engage à vous prévenir d'une chose. C'est qu'on a donné les ordres les plus sévères pour empêcher l'introduction des Raynal en France. C'est que l'on est instruit qu'il se fait en 4 endroits. C'est qu'on a déjà envoyé des particuliers déguisés pour examiner l'impression, pour s'informer de la route que les livres doivent prendre. Je ne vous en dis pas davantage, mais ce que je vous dis, je le tiens de bonne part. On veillera de près. ${ }^{57}$

Six months later he put the publishers on guard against spies who were after their edition of Mercier's prohibited Tableau de Paris: "Prenez garde à vous pour le Tableau de Paris; vous serez surveillé de près. Je vous préviens et je sais cela de bonne part." ${ }^{58}$ Brissot made a less guarded reference to his source in a letter informing the Society of the race to publish editions of Rousseau's works, as it was viewed by the authorities responsible for suppressing them. "A propos de Rousseau, j'oubliais de vous dire que $M$. Martin de la police me disait l'autre jour qu'il n'y en avait que neuf éditions en train, ce qui allait inonder la France. La vôtre sera goûtée, si vous parvenez à la faire entrer promptement." 59 Martin was the secretary of police in charge of "tout ce qui concerne la Bastille, Vincennes et autres châteaux où sont renfermés les prisonniers de l'Etat, la librairie prohibée, etc.," as his job was defined in the Almanach royal. He was the key official whom anyone involved with the clandestine book trade would want to know, for he could provide information about competitors, warning of repressive measures, and assistance when books got caught in the machinery for keeping prohibited works outside France and for protecting the monopoly of the booksellers' guild. Martin's friendship could be a powerful weapon in the rugged world of eighteenth-century publishing, as an agent of the Société Typographique de Neuchâtel, Quandet de la Chenal, informed it in 1781: "On va me faire faire connaissance avec M. Martin, premier commis à la police pour la partie de la librairie.

${ }^{57}$ Brissot to the Société Typographique de Neuchâtel, July 26, 1781, Bibliothèque Publique de la Ville de Neuchâtel, MS 1128.

${ }^{58}$ Brissot to the Société Typographique de Neuchâtel, Jan. 12, 1782, Bibliothèque Publique de la Ville de Neuchâtel, MS 1128.

${ }^{59}$ Brissot to the Société Typographique de Neuchâtel, Apr. 23, 1781, Bibliothèque Publique de la Ville de Neuchâtel, MS 1128. Brissot also indicated an official source for his report of the government's measures against the continuation of Linguet's Annales politiques, civiles et littéraires du dix-huitième siècle by Mallet du Pan: "Soyez sûr qu'il ne perce ici aucun des journaux Mallet. Tous ont été saisis. J'en crois l'homme même qui les a fait saisir" (Brissot to the Société Typographique de Neuchâtel, Aug. 18, 1782, Bibliothéque Publique de la Ville de Neuchâtel, MS 1128). 
Plusieurs de ses amis que j'ai l'honneur de connaître m'ont promis de me rendre ce service. Ce commis est extrêmement lié avec M. Boucherot, et M. Boucherot vous veut du bien. C'est par son moyen que le dernier a fait relâcher et transporter chez M. Perre les balles des Arts qui m'ont été remises." 60

Brissot knew Martin well. He wrote to the Society, not without a touch of pride, that "M. Martin, qui a l'air de m'estimer, de m'être attaché, m'a protesté de tout son zèle." 61 This friendship apparently came to full bloom in the Bastille and had to be eradicated, like the Bastille, after July 14, 1789. For July 14 metamorphosed Martin into a villain, snatched away his job, and replaced him with none other than Manuel. (The Revolution, to the populace of Grub Street, meant not only freedom from embastillement but employment-in the new journals bursting out all over Paris and in the new state bureaucracy.) As inspector of publishing, Manuel did little more than gather material for his own works, and so he was hailed as a defender of the freedom of the press by Brissot, editor of the successful new journal, Le Patriote Français: "Notre ami Manuel tient au département de la police un langage bien différent de son prédécesseur Martin, qui distribuait les lettres-decachet, qui l'a torturé, comme moi, dans l'antre de la Bastille. M. Manuel est digne d'être républicain, il fait le moins qu'il peut." ${ }^{62}$ Brissot had talked another language himself before these happy transformations. Having taken care to work his way into Martin's favor, he sent his "torturer" a bread and butter letter soon after his release from the Bastille:

Je profite de mon premier moment de repos pour vous réitérer tous mes remerciements pour l'intérêt que vous avez pris à mes malheurs...

Voulez-vous bien faire agréer mes respects à Monsieur Lenoir et tous les sentiments de la reconnaissance que ses procédés généreux et délicats m'ont inspirés, ainsi qu'a mon épouse? Agréez pour vous-même ses civilités et ses remerciements.

Je suis, avec toute la considération possible, Monsieur, votre très humble et obéissant serviteur. ${ }^{63}$

${ }^{60}$ Quandet to the Société Typographique de Neuchâtel, June 20, 1781, Bibliothèque Publique de la Ville de Neuchâtel, MS 1203. Quandet was referring to a seizure of a shipment of the nineteen-volume Description des arts et métiers, which was published by the Society and banned from France, owing to the machinations of one of the Society's French competitors.

${ }^{61}$ Brissot to the Société Typographique de Neuchâtel, Mar. 30, 1782, Bibliothèque Publique de la Ville de Neuchâtel, MS 1128.

62 Le Patriote Français, July 31, 1790.

${ }^{63}$ Brissot to [Martin], Oct. 21, 1784, in Brissot, Correspondence et papiers, pp. 83-85. The context of this letter indicates that its unnamed addressee was very probably Martin. 
What kind of a serviteur of Martin's was Brissot? Certainly one who had access to inside information. After the police confiscated some of the Society's illegal books, Brissot wrote, "Quoique je n'aie pas pu voir M. Quandet, cependant je sais qu'il a présenté un bon mémoire au lieutenant de police, et qu'il s'est très bien conduit. Je sais qu'on a été content de lui. Je verrai M. M- demain pour le sonder." ${ }^{44}$ By February 1785, Quandet had lost his job as a result of one of its occupational hazards, a lettre de cachet, but Brissot remained firmly within the circle of Martin's confidants, according to Quandet's successor.

M. de Warville m'a dit, qu'à la dernière conversation qu'il a eu [sic] avec M. Martin, premier secrétaire de M. le lieutenant-général de police, il lui avait dit qu'il ne concevait pas que malgré les ordres précis qu'il avait donné [sic] sur la frontière de Suisse, quelle route nous pouvions prendre pour faire passer à Paris nos livres, mais que par la suite il saurait prendre tant de précautions qu'enfin il saurait découvrir nos moyens. Il n'a voulu accorder à M. de Warville que pour 200 exemplaires des tomes $6,7,8$ et 9 de Bibliothèque l'entrée à Paris. ${ }^{65}$

At least this much can be untangled from this letter's knotty syntax: the police were cracking down on smuggling from Neuchâtel but were willing to let a limited number of Brissot's prohibited books slip through their fingers, and Brissot was meeting, probably regularly, with the police secretary in charge of the book trade in early 1785 , exactly as Lenoir claimed.

By comparing Lenoir's claims and Brissot's correspondence with his publishers, it seems reasonable to conclude much more. Brissot sent inside information to Neuchâtel because he really was an insider among the secret police of Paris, as his enemies charged. He probably was a spy, and his spying probably concerned the libelle style of pamphleteering that contributed to his support before the Revolution and his downfall during it. This conclusion fits the picture of his desperation in the last half of 1784 that emerges from his and Clavière's correspondence with the Société Typographique de Neuchâtel, published above. Agonizing over the collapse of his ambitions, the welfare of his sick wife and infant, the perfidy of his enemies, the gloom of the Bastille, and the imminence of bankruptcy, he evidently offered his services to Lenoir, perhaps for the 150 livres a month mentioned by Marat, Rivarol, and Desmoulins, because spying opened up a way out of his distress, maybe even a way out of the Bastille. Brissot eventually found a more important "out" in the financial patronage of Clavière, but that is another story.

${ }^{64}$ Brissot to the Société Typographique de Neuchâtel, Sept. 22, 1782, Bibliothèque Publique de la Ville de Neuchâtel, MS 1128.

65 J. F. Bornand to the Société Typographique de Neuchâtel, Feb. 19, 1785, Bibliothèque Publique de la Ville de Neuchâtel, MS 1124. 


\section{Robert C. Darnton}

The story of his spying deserves emphasis, not in order to pass judgment on Brissot, but in order to understand him. His embastillement did not prove the purity of his patriotism, as he argued later; it corrupted him and in corrupting must have confirmed his hatred of the Ancien Régime. How he must have hated it! How he must have raged inwardly against the system of arbitrary power that first struck him down and then enlisted him in its service and against the men in control of the system, who first blocked his attempts to win honor for himself and then dishonored him by making him their agent! No wonder that his rage broke out during the Revolution in declamations against the debauchery of Lenoir and the other men at the top of the Ancien Régime: They had deflowered the earnest young bourgeois who had left Chartres to pursue the dream of becoming a philosopher. There was consolation in the thought that "they"-the aristocratic gens en place-had also corrupted Rousseau, whose inner self nonetheless remained pure, as Brissot knew in 1784 from his third reading of the Confessions. Brissot had more reason than most to identify himself with Rousseau- "Je souffre moi-même quand je le lis; j'entre dans ses douleurs, et je me dis: que n'ai-je été assez heureux pour le connaître? Comme je lui aurais ouvert mon âme!"68_because, like Jean-Jacques, he invented a fictional self to compensate for the failings of his real self. Brissot called this other self Phédor: "Phédor a l'âme droite et un profond amour de la justice; la bienveillance est la base de son caractère ... Quand il mourra, il présentera devant le souverain juge une âme pure et aimant la vertu." ${ }^{67}$ Phédor was the young philosopher of Chartres who had preserved his virginity; he was the hero of Brissot's memoirs, which Brissot wrote after reading the Confessions for the sixth time and before presenting his case to the Revolutionary Tribunal, from which he could only appeal to posterity.

To expose the fictional Brissot of the memoirs is not to rob the real Brissot of the typicality that historians have attributed to him. Brissot's Rousseauistic ideals do typify those of his contemporaries, but idealism did not take a provincial bourgeois far in prerevolutionary France. When Brissot found his way blocked, he had to compromise with the system. When it imprisoned him and confiscated his works, he came to an understanding with its police. When it failed to provide him with a living as a philosophe, he became a hack pamphleteer and a mouche.

${ }^{66}$ Journal du Licée de Londres, I, 223. On p. 225 Brissot described the state of his "âme èlectrisée" after reading the Confessions for the third time.

${ }^{67}$ Brissot, Mémoires, I, 14, 18. Brissot acknowledged the model for his "portrait de Phédor"- "La lecture des Confessions de Rousseau, que je reprends pour la sixième fois, me rapelle quelques traits qui lui conviennent" (ibid., I, 18) - and for his memoirs-"Je vais imiter Rousseau" (ibid., I, 24). 
And when the Revolution arrived, he threw himself into it, not as the disinterested idealist of the memoirs, but as a failure from the old system who was determined to redeem himself in the new. The Revolution made Brissot the prominent and fairly prosperous editor of Le Patriote Français, the powerful leader of the Girondins. Is it surprising, then, that the sans-culotte "anarchy" of 1793 threatened everything that, after years of struggle and humiliation, he had finally won, everything that, for him, was the Revolution? Brissot's fellow pamphleteers in the 1780's probably hated the social system and made necessary compromises with it as he did. They were men of flesh and blood who needed to support families, satisfy ambitions, and pursue pleasures. Their failures and frustrations in the old order may serve as a measure of their dedication to the new, and the Revolution may be understood, from their point of view, as a career. The study of careers, old fashioned and merely biographical as it seems, may provide a needed corrective to the more abstract study of ideas and ideologies. The intellectual origins of the Revolution and the character of its politics may be understood better if one descends from the level of the Encyclopédie and the podium and re-enters Grub Street, where men like Brissot produced the papers, pamphlets, and placards, the songs, cartoons and rumors, that built personal quarrels and factional rivalries into an ideological struggle over the destiny of France. 